\title{
Green Peptide-nanomaterials; A Friendly Healing Touch for Skin Wound Regeneration
}

\author{
Debjani Nath*, Pratyusha Banerjee, Anugrah Ray, Baishakhi Bairagi \\ Department of Zoology, University of Kalyani, Kalyani, Nadia Pin 741235 \\ *Corresponding author email: nath_debjani@yahoo.co.in
}

Received: 25 February 2019 / Accepted: 21 March 2019 / Published: 22 March 2019

\begin{abstract}
The complex phenomenon by which the body responds to any injury of skin or tissue is known as wound healing. A number of phases like exudative, proliferative, and extracellular matrix remodeling are orchestrated events to be occurred involving blood cells, parenchymal cells, and different soluble mediators. Different internal, as well as external factors, regulate the speed and quality of healing. The delay in wound healing process causes the chronic wound or scar formation. At the present moment, the upscale research for identification of agents causing accelerated healing is important. Moreover, the biocompatibility of the accelerators needs to be investigated. Recent biomedical researches for wound care target to provide antimicrobial protection as well as matrix scaffolding for quick repairing of the skin tissue. In recent studies with natural peptides have shown that they are important components in developing the nano-medicines for their usefulness and therapeutic efficiency. New therapeutic formulations can be developed using these natural peptides utilizing different nanoparticle delivery system. This review deals with the developmental study on efficient wound care system where the possible use of natural peptides in combination with nanomaterials has been explored. A trial has also been made on the findings made over the past few years on the use of peptides as tissue regenerating agents through effective wound healing pathway.
\end{abstract}

Keywords: wound healing; tissue regeneration, nanomaterial; green peptide nanoparticles; biocompatibility; bioactive.

\section{Introduction}

The experimental research in the field of application of nanomatrials has shown a monumental rise in very recent years. The typical focus of nanoparticle research is to design the nanoparticles (NPs) pointing different strategies related to its use in resolving environmental and biomedical problems such as therapeutics, drug delivery, imaging, etc. [1-4]. In comparison to the bulk material the nano form of the particles possess large 'surface-to-volume' ratio that makes them suitable for applications in different fields of life. Thus, the emphasis on synthesis and analysis of NPs from various noble metals like silver, gold, platinum, etc has been put forward. The metal nanoparticles can be synthesized by the conventional method using different chemicals as reducing agents to obtain desired nanostructures with controlled physical and chemical properties [5-7]. However, the use of hazardous conditions, toxic solvents, high amounts of energy and pressure can be mentioned as the negative points of these processes.

The methods involved in the synthesis of metal nanoparticles are still at the stage of infancy and thus problems related to the stability, crystal growth, aggregation etc. are the major concern of the researchers [5-7]. Therefore, it is needed to be developed a new synthetic approach for designing nanomaterials with all the desired features having lesser toxicity to the environment as well as living system. Green strategies have been considered as the environmentally sustainable nontoxic approach in this regard. During the course of time a number of new green strategies have been evolved. The most important criteria of choosing a green approach depends solely on the inducing capacity of the selected biomolecules to generate nanoforms along with its ability to manipulate the size and structural organization of it avoiding the problem 
of aggregation [8-18]. Several evidences have shown the formulation of nanoparticles using different small biomolecules like monosaccharides (glucose or galactose), amino acids, short peptides isolated from plant [8-18]. Complex biomolecules like long chain peptides and microorganisms have also been used efficiently for reduction of metal ions to its nano form and this nano-conjugates have also been found to have significant potential in therapeutics [14-17].

An extensive study has been forged to identify the natural peptides having potential therapeutic value but investigation on clinical translation revealed their limitation due to the inefficient delivery at the target sites in vivo [19]. Therefore, it is important to revisit this field of study so that new strategies can be advocated to facilitate the target specific delivery of the peptide conjugated nanomaterials. On the other hand, natural peptides have unique properties to enhance the efficiency of different therpeutiac agents carried with NPs. Moreover, the discussion on peptide-nanomaterials in medical biology reveals that the current applications of biosynthesized nanoparticles in the field of molecular biology includes the development of nanostructures, nano-devices, and nano-systems that have the capacity to revolutionize the medical therapeutics and diagnostics. These bio-synthesized nanodevices are innovative, less toxic, environment friendly and biocompatible. They also provide other advantages like the ability of crossing cellular barriers activating various cellular transport systems $[20,21]$. They can also impose biocompatibility and safety profiles through the nanodelivery systems [22]. Nano-therapeutics can be included in the modern health care technologies to upgrade the quality of healthcare and to face the challenges of difficult prognosis like issues related to tissue regeneration and wound repairing. [23]. There are several behavioral factors of individuals that can affect the rate and quality of healing like aging, co-morbidity, stress, smoking or drinking, infections, malnutrition etc. The wound environment is another significant factor to be considered. If the environment is not suitable enough then it can cause the delay in the healing process causing chronic wound or scar formation like diabetic wound repairing.

Several wound healing agents have been studied so far. Either they are derived from natural sources like plants and animals or are developed through chemical synthesis. The natural products seem to be safer for the tissues due to their biocompatibility. In this review we will discuss different kinds of the animal as well as plant-derived peptides and their role as wound healing accelerator when combined to nanomaterials. Green nanomaterials are more environment friendly due to its anti microbial efficacy, anti inflammatory action, natural moisturizing efficacy, biocompatibility with skin and other tissues. In this review we have focused on recent advances in building strategic approach of synthesizing peptide-nanomaterials and their use in skin wound healing and tissue regeneration.

\section{Peptides and Their Bioactivity}

Peptides are found to have specificity for biological targets and thus they have been emerged as promising agents in medical therapeutics. But recent investigations have revealed that it is important to incorporate the peptides with the nanoparticle delivery system for effective implication in nanomedicine.

\subsection{Bioactive Peptides}

The peptides are known to be versatile as they do participate as integral part of different metabolic processes of body system like immunological and enzymatic network and nutrition and storage devices. They can act as transporters, signaling molecules as well as regulatory mediators. Other than these they also act as antimicrobial agents and antioxidants. Peptides also have the ability to interact with cellular membranes in a nonreceptor-ligand type of binding. These efficiencies made them eligible for cellular therapeutics. Already a list of over 1500 peptides has been described (Table1). The origin of these listed peptides includes insects, amphibians, plants, mammals as well as microorganisms, [24]. Initially, some peptides having antimicrobial efficacy were isolated and identified from the skin of frogs and lymph from insects. Peptides are ubiquitously distributed in all invertebrates as suggested by Boman with other group of researchers [25,26-30]. VK25 is a peptide first identified from the Komodo dragon (Varanus komodoensis), is a cationic antimicrobial peptide (CAMP). 
Nath et al., Adv. Nan. Res.; Vol. 2 Issue 1, pp: 14-31, 2019

Table 1: Plant derived peptides with antibacterial activity

\begin{tabular}{|c|c|c|c|}
\hline Peptide & Source & Family & Activity \\
\hline Cn-AMPI & Cocos nucifera & - & Gram+/Gram- \\
\hline Cn-AMP2 & Cocos nucifera & - & Gram+/Gram- \\
\hline Cn-AMP3 & Cocos nucifera & - & Gram+/Gram- \\
\hline Сy-AMP1 & Cycas revoluta & - & Gram+/Gram- \\
\hline Су-АMP2 & Cycas revoluta & - & Gram+/Gram- \\
\hline Dendrocin & Dendrocalamus latiflora & - & Grarn+/Grarn- \\
\hline Ginkbilobin & Ginkgo biloba & - & Gram+/Gram- \\
\hline Lunatusin & Phaseolus Iunatus & - & Gram+/Gram- \\
\hline Circulin A & Chassalia parviflora & Cyclotide & Grarn+/Gram- \\
\hline Circulin B & Chassalia parviflora & Cyclotide & Gram+/Gram- \\
\hline Cyclopsychotride A & Psychotria tongipes & Cyclotide & Gram+/Gram- \\
\hline Kaiata B2 & Oldenlandia affinis & Cyclotide & Gram+ \\
\hline Ah-AMP1 & Aesculus hippocastanum & Defensin & Gram+ \\
\hline Cp-Defensinll & Vigna unguiculata & Defensin & Gram+/Gram - \\
\hline Fabatin-1 & Vicia faba & Defensin & Gram+/Gram- \\
\hline Fabatin-2 & Vicia faba & Defensin & Gram+/Grana- \\
\hline Pp-AMP 1 & Phyllostachys pubescens & Defensin & Gram+1Gram- \\
\hline Pp-AMP2 & Phyllostachys pubescens & Defensin & Gram+/Gram- \\
\hline Pp-Defensin & Pyrularia pubera & Defensin & Gram+/Gram- \\
\hline Pth-Stl & Solanum tuberosum & Defensin & Gram+/Gram- \\
\hline So-D1 & Spinacia oleracea & Defensin & Gram+/Gram - \\
\hline So-D2 & Spinacia okracea & Defensin & Gram+/Gram- \\
\hline So-D3 & Spinacia okracea & Defensin & Gram+/Gram- \\
\hline So-D4 & Spinacia oleracea & Defensin & Grarn+/Gram - \\
\hline So-05 & Spinacia oleracea & Defensin & Gram+/Gram- \\
\hline So-D6 & Spinacia okeracea & Defensin & Gram+/Gram- \\
\hline So-D7 & Spinacia okracea & Defensin & Gram+/Gram - \\
\hline Tu-AMP 2 & Tulipa gesneriatza & Defensin & Gram+/Gram - \\
\hline Tu-AMP-1 & Tulipa gesneriana & Defensin & Gram+/Gram- \\
\hline $\mathrm{VaD} 1$ & Vigna angularis & Defensin & Gram+/Gram- \\
\hline lirD1 & Vigna radiata & Defensin & Gram- \\
\hline $\mathrm{VrD} 2$ & Vigna radiata & Defensin & Gram+/Gram- \\
\hline White cloud bean defensin & Phaseolus vulgaris & Defensin & Gram+/Gram- \\
\hline Brazzein & Pentadiplandra brazzeana & Defensin & Gram+/Gram- \\
\hline Sesquin & Vigna sesquipedatis & Defensin-like & Gram+/Gram- \\
\hline Coconut antifungal Peptide & Cocos nucifera & Glutamic acid-rich & Gram+/Gram- \\
\hline Pg-AMP 1 & Psidium guajava & Glycine-rich & Gram- \\
\hline Ac-AMP1 & Amaranthus caudatus & Hevein-I ike & Gram+ \\
\hline Ac-AMP2 & Amaranthus caudatus & Hevein-I ike & Gram+ \\
\hline Ee-CBP & Euonymus europaeus & Hevein-like & Gram+ \\
\hline Fa-AMP1 & Fagopyrum esculentum & Hevein-like & Gram+/Gram - \\
\hline $\mathrm{Fa}-\mathrm{AM}$ P2 & Fagopyrum esculenturn & Hevein-I ike & Gra m+/Gram - \\
\hline Pn-AMP1 & Pharbitis nil & Hevein-like & Gram+/Gram- \\
\hline Pn-AMP2 & Pharbitis nil & Hevein-I ike & Gram+/Gram- \\
\hline WjAMP1 & Eutrema wasabi & Hevein-like & Gram+/Gram- \\
\hline Ib-AM P1 & Impatiens balsamina & Impatiens & Gram+/Gram- \\
\hline Ib-AMP4 & Impatiens balsamina & Impatiens & Gram+ \\
\hline Mc-AMP1 & Mesembryanthemum crystallinum & Knottin & Gram+ \\
\hline Mj-AMP1 & Mirabilis jalapa & Knottin & Gram+ \\
\hline Mj-AMP2 & Mirabilis Jalapa & Knottin & Gram+ \\
\hline Pa-AMP 1 & Phytolaccaa mericana & Knottin & Gram+ \\
\hline Pa-AMP2 & Phytolaccaa mericana & Knottin & Gram+ \\
\hline MBP-1 & Zea mays & MBP-1 & Gram+/Gram- \\
\hline Shepherin & Capsella bursa-pastoris & Shepherin & Gram+/Gram- \\
\hline Shepherin II & Capsella bursa-pastoris & Shepherin & Gram+/Gram- \\
\hline Snakin-1 & Solanum tuberosum & Snakins & Gram+/Gram- \\
\hline Snakin-2 & Solanittntuberosum & Snakins & Gram+/Gram - \\
\hline Vicilin-like Antimicrobial peptide $2 \mathrm{a}$ & Macadamia integrifolia & Vicilin-like & Gram+ \\
\hline Vicilin-like Antimicrobial peptide 2b & Macadamia integrifolia & Vicilin-like & Gram+ \\
\hline Vicilin-like Antimicrobial 2c-1 & Macadamia integrifolia & Vicilin-like & Gram+ \\
\hline Vicilin-like Antimicrobial peptide 2c-2 & Macadamia integrifolia & Vicilin-like & Gram+ \\
\hline Vicilin-like Antimicrobial peptide 2c-3 & Macadamia integrifolia & Vicilin-like & Gram+ \\
\hline Vicilin-like Antimicrobial peptide 2d & Macadamia integrifolia & Vicilin-like & Gram+ \\
\hline
\end{tabular}


After this discovery, scientists have designed a synthetic peptide DRGN-1 taking VK25 as an inspiration. This peptide has two amino acid residues taken from the original protein sequence of the dragon's VK25 [31]. Another peptide named cathelicidin-OA1 was identified by Cao et al (2018) [32]. The source of this peptide is the skin of an amphibian species (Odorrana andersoniz). This peptide is originated by the cleavage of a prepropeptide having the length of 198 amino acids. The amino acid sequence of cathelicidin-OA1 is 'IGRDPTWSHLAASCLKCIFDDLPKTHN' and its molecular mass is $3038.5 \mathrm{kDa}$. Cathelicidin-OA1 is found to promote healing of wounds in mouse model having full-thickness skin wounds by accelerating the re-epithelialization. It also induces the formation of granulation by stimulating the assemblage of macrophages to the site of damage. As the bioactive peptides act as antibacterial, antiviral, antifungal, and/or antiparasitic agents and possess the antioxidant activity they are crucial in medical research specifically in healing wounds. Most of the bioactive peptides are rich in cysteine or glycine residues. They have disulphide bridges between the cysteinyl residues to increase their stability. They also contain charged amino acids and hydrophobic domains. The amino acids are primarily cationic. Peptides having cationic charge are potent antibacterial or antiviral agents though few examples of anionic peptides also exist. $\beta$ sheets or $\alpha$-helices of these molecules are either looped or extended. Different structureal combinations of these domains are found in the natural bioactive peptides [27,28, 33-43]. The peptides are of three types viz. cell-penetrating peptides, antimicrobial peptides, and peptide toxins.

\subsubsection{Cell Penetrating Peptides}

In order to function in the cytosol, the peptides - nanoparticles conjugate must cross the plasma membrane. Over the past 25 years, a large volume of research has been focused on the development of peptide agents capable of increased uptake of cargoes into the cell ranging from individual protein molecules [44] to liposomes with diameters of $200 \mathrm{~nm}$ [45]. These cell-penetrating peptides (CPPs) have been originated from natural translocating proteins that are capable to cross biological membranes. The first evidence of the CPPs was found in the HIV-1 trans-activator of transcription (Tat) protein. TAT can penetrate cellular membranes by an energy-independent pathway they can be accumulated in the nucleus [46,47]. Further investigation revealed that a minimum peptide sequence is required for its uptake into the cell [48] and this leads to the discovery of different CPPs. One of such CPPs is penetrating. It was first identified in the homeodomain of the Drosophila antennapedia protein [49]. A large number of CPPs have been identified from various sources. Some of these sources are viral proteins [50], animal venoms [51] and synthetic peptide libraries [52]. The structural organization revealed that these peptides are typically 5-30 amino acids long having versatility in their structural and chemical properties thus these are very effective as bioactive molecules and nanoparticle delivery agents. A comprehensive list of CPPs is found in the review by Milletti [53].

\subsubsection{Peptide Toxins}

Animal venoms are the most potentially active biomolecules with broad therapeutic applications [54]. The composition of venom shows the presence of various bioactive peptides. These peptides are capable of inducing the pharmacologic response after its delivery to the recipient [55]. They are highly potent and specific and thus of great interest. venom peptides are an attractive tool for probing the structure and they are specific for targets like voltage-gated ion channels, nicotinic acetylcholine receptors, N-methyl-Daspartate (NMDA) receptors, and acid-sensing ion channels (ASICs) [56]. They also act as templates for synthesizing drugs that can target different receptors. Many of these drugs have already been successfully translated to the clinic.

\subsubsection{Antimicrobial Peptides}

Antimicrobial peptides can combat the problem of antibiotic resistance and multidrug resistance avoiding the conventional mechanisms of resistance and they form the basis of a new class of therapeutics [57,58]. They are found in a variety of organisms and perform the antimicrobial activity by disrupting biological 
membranes, leading to depolarization, lysis, and cellular death of the microorganisms. Structural organization of AMPs reveals that these are short peptides having 10-50 amino acids long residues, cationic having charge in between +2 to +9 with a number of hydrophobic residues that can interact with the lipid membranes [59]. AMPs are extremely diverse; more than 1,200 peptides have already been identified which can further be divided into five structural classes. A variety of mechanistic pathways have been proposed [60]. AMPs do not target a specific molecule or biochemical process, but it provides them with the broadspectrum activity [61].

One of the key concerns of using these AMPs in eukaryotic system is the toxicity. Moreover, the free AMPs get cleared rapidly by the kidney and thus have poor pharmacokinetic profile [62]. So, efforts are being made to overcome such limitations by enhancing antimicrobial efficacy with minimized toxicity to eukaryotic cells. Therefore, nanoparticle-based strategies have been developed to improve the AMP delivery reducing their off-target treatment effects along with lesser toxicity. Jallouk et al. incorporated melittin into the lipid monolayer of perfluorocarbon nanoparticles to reduce the toxicity to sperm and vaginal epithelium [63] but their antiviral activity against HIV-1remained unaltered [64]. These findings demonstrated the potential usefulness of melittin-loaded nanoparticles as a topical vaginal virucide. Another example is the incorporation of the LL-37 (an AMP derived from human cathelicidin) into polymer nanoparticles found to retain its activity against Escherichia coli [65]. It was found that LL-37-loaded nanoparticles cause sustained LL-37 release and improved wound healing in a mouse injury model.

\subsection{Bioactive Green-peptides of Plant Origin}

Different AMPs act as important immunological barriers not only against the microorganism but also against different microbial infections. The AMPs are also found to represent another aspect of the resistance phenomenon commonly termed as hypersensitive response (HR). Generally, the antimicrobial peptides of plants are capable of production of ROS (reactive oxygen species), NO (nitric oxide), and SA (salicylic acid), in resistance to the infection. As AMPs potentially active against a variety of infectious agents they can also be classified as antibacterial, fungicides, antiviral, and antiparasitic. The antibacterial activity of these peptides is contributed by the motifs possessing high density of positively charged residues within the structure [66-69]. This structural organization leads to the peptide attachment and insertion into the bacterial membrane creating transmembrane pores resulting membrane permeabilization. The hydrophobic motifs are directly responsible for the interaction with the lipid components of the membrane, while the hydrophilic cationic groups produce link with the phospholipid groups found to be present in the membrane.

The AMPs are antifungal as they can cause fungal cell lysis or even interfere with the fungal cell wall synthesis. Peptide binding induces fungal membrane permeabilization and/or pore formation [70-73, 7679]. Structural variation is found in the arrangement involving polar as well as neutral amino acids of the plant derived peptides having different functional activities $[71,74,75,80]$. The antifungal peptides differ from the antibacterial peptides by the absence of the conserved structural domains associated with antifungal activity [66, 67, 73,81-88]. The AMPs are also found to possess the antiviral activity. The effectiveness of these peptides mainly depends on their ability to interact with the membrane by means of electrostatic association. Negative charges of glycosaminoglycans facilitate the binding of AMP and compete with the viruses [71]. Purothionin is the first plant-derived AMP. This peptide is potentially effective against Pseudomonas solanacearum, Xanthomonas phaseoliand X.campestris, Erwinia amylovora, Corynebacterium flaccumfaciens, C. michiganense, C. poinsettiae, C. sepedonicum, and C. fascians [89]. The peptides that have been identified till date belong to the major groups including thionins (types I-V), defensins, cyclotides, $2 \mathrm{~S}$ albumin-like proteins, and lipid transfer proteins [73,83, 86-88].

Some AMPs that are not so common are vir: knottin-peptides, impatiens, puroindolines, vicilin, shepherins, snakins, and heveins [90-99]. There are evidences suggesting the full isolation of plant AMP in some plants. One such example is the isolation of purified lunatusin from Chinese lima bean (Phaseoluslunatus L.). It is a peptide having the molecular mass of $7 \mathrm{kDa}$. Lunatusin is found to be effective against Bacillus subtilis, $B$ 
megaterium, Proteus vulgaris, and Mycobacterium phlei. It has antifungal activity on Fusarium oxysporum, Mycosphaerella arachidicola, and Botrytis cinerea. But only after incubation with trypsin the peptide retains its antifungal activity [100]. This peptide was demonstrated to have a mitogenic response in mouse splenocytes [100] and proliferation of breast cancer MCF-7b cell line. Vulgarinin is another example of AMP. The source of this peptide is the seeds of haricot beans (Phaseolus vulgaris). The peptide is of a molecular mass of $7 \mathrm{kDa}$. It is effective against Mycobacterium phlei, Bacillus megaterium, B. subtilis, and Proteus vulgaris species of bacteria and Fusarium oxysporum, Mycosphaerella arachidicola, Physalospora piricola, and Botrytis cinerea species of fungus. Its antifungal activity was also retained after incubation with trypsin. Researches revealed that vulgarinin was effective in inhibiting the proliferation of leukemia L1210 and M1 cell lines and breast cancer MCF-7 cell line [101], and thus assumed to have the cytotoxic and antioxidant properties. Another peptide isolated from the seeds of Amaranthus hypochondriacus also displays antifungal activity [101]. Hispidulin purified from seeds of Benincasa hispida with a molecular mass of $5.7 \mathrm{kDa}$ composed of 49 amino acid residues is also found to display broad and potent inhibitory effects against various human bacterial and fungal pathogens [102]. Two another antifungal peptide viz. cicerin and arietin, were isolated from seeds of chickpea (Cicer arietinum) found to have novel $\mathrm{N}$-terminal sequences. These peptides have molecular masses of approximately 8.2 and $5.6 \mathrm{kDa}$ respectively. Arietin expressed higher translation inhibitory activity in a rabbit reticulocyte lysate system and higher antifungal potency toward Mycosphaerella arachidicola, Fusarium oxysporum, and Botrytis cinereathan cicerin [103,104]. AMPs from dry seeds of Phaseolus vulgaris cv. exhibit both antifungal and antibacterial activity [105]. Another AMP (So-D1-7) was isolated from a crude cell wall preparation of spinach (Spinacia oleraceacv) and found to be active against Gram-positive (Clavibacter michiganensis) and Gram-negative (Ralstonia solanacearum) bacterial pathogens, as well as Fusarium culmorum, F. solani, Bipolarismaydis, and Colletotrichum lagenarium of fungal species [99].

Antiparasitic peptides are another group of bio-active peptides. Following an initial report describing the lethal effect of magainin isolated from Xenopus sp skin on Paramecium caudatum, another peptide (cathelicidin) confirmed the antiparasitic activity of AMPs [106-110]. Vegetable priteinases are responsible for the Antihelmintic activity. Bromelain a stem enzyme of Ananas comosus shows antihelmintic effect against Haemonchus contortus [106-110]. Its activity is quite similar to that of the reference drug pyrantel tartrate. Similar effects were confirmed with different proteinases isolated from plants like Carica papaya, A. comosus, Ficus carica and Egyptian Asclepias inaica when tested in vitro against the rodent gastrointestinal nematode Heligmosomoides polygyrus [111]. The proteolytic effect of the proteinases cannot fully explain the antihelmintic effect because the inhibited enzymes also partially preserve the antiparasitic activity.

Defensins are another group of AMPs. According to one group of investigators this AMPs are 18 to 48 amino acids residue long while according to the other group these peptides are 12-54 amino acid residues long. These are cysteine-rich globular AMPs present in plants [112] and possess four disulphide bridges $[112,113]$. These peptides were first described in human neutrophils [113,114], but later found in human, chimpanzee, rat, mouse, marine arthropods, plants, and fungi [115-118]. Defensins are structurally classified into four different categories [119-122]. Group I cause inhibition of Gram-positive bacteria and fungi. Group II shows antifungal activity but not antibacterial. Group III are active against both Gram-positive and Gram-negative bacteria but inactive against fungus. Finally group IV are effective against Grampositive and Gram-negative bacteria along with fungus. Specific determinants of each group are responsible for the microbe specific activities of the peptides, these determinants are responsible for targeting different groups of infectious agents. Several defensins have been purified from different plants and are found to have activity against Candida albicans, C. parapsilosis, C.tropicalis, C. guilliermondii, Kluyveromyces marxiannus, and Saccharomyces cerevisiae, Fusarium oxysporum, F. solani, F. lateritium, and Rhiroctonia solani . An antifungal peptide $(7.3 \mathrm{kDa})$ was purified from dried seeds of Phaseolus vulgaris. It is antifungal activity against Mycosphaerella arachidicola and also against Fusarium oxysporum [106]. From germinated seed of lentil (Lens culinaris), a 47amino-acid (Lc-def) defensin was purified. The molecular mass is $5.4 \mathrm{kDa}$. This peptide shows homology in sequence with the defensins isolated from legumes. It exhibits antifungal activity against Aspergillus niger $[104,123]$. Another defensin isolated from the seeds of Phaseolus vulgaris cv. having a molecular mass of 5.4 
$\mathrm{kDa}$ with an $\mathrm{N}$-terminal sequence, shows inhibitory activity against Mycosphaerella arachidicola, Setosphaeria turcica, and Bipolaris maydis.

The bioactivity of these peptides are not only restricted as antimicrobial but many plant peptides and proteins evolved as signaling molecules and play a crucial role in homeostasis, defense, growth, differentiation, and senescence. These signaling peptides encompass highly diversified sequences showing variation within and across species and without a common phylogenetic origin. And thus, they cannot be classified in a single group [124-127]. However, a classification based on their suggested functions like homeostatic, innate immune responses (defensive), expansion and proliferation, organ maintenance and organogenesis, and sexual related functions can be done. The homeostatic function is performed by three peptide classes viz. natriuretic class (PNP), phytosulfokines (PSK), and rapid alkalinization factors (RALF). PNP has been purified from several species [125-128]. PSKs are sulphated penta-peptides with two sulphated Tyr residues synthesized as precursors. The phytosulfokine receptors (PSKR) displays guanylate cyclase activity $[129,130]$. The RALF factors are $5 \mathrm{kDa}$ peptides in plant roots and are associated with hair growth control $[130,131]$.

There is another family CLE which includes all the different groups of peptides that are capable of triggering signaling pathways. CLV3 (CLAVATA 3) of Arabidopsis thaliana is a 13-residue long peptide that plays an important role in stem cell differentiation during meristematic development [132-134]. From these examples it is evident that the bioactive peptides derived from plants possess microbicide efficacy and are also involved in different signaling cascades related to important physiological functions.

\section{Peptides in Nanoparticle Synthesis}

The peptides are natural compounds in synthesizing the biocompatible metal nanoparticles in mild conditions [135-139]. They act as reducing agent as well as the capping agent during nanomaterials synthesis. There is enormous scope of use these peptides to bind, interact, and/or direct the regulated synthesis of nanoparticle with desired shape, size, structure and surface composition. Utilization of these peptides in the process of synthesis makes the process more varied and innovative [140]. These peptides not only reduce the bulk metal into nanoparticles but also act as the mold for the growth of metal nanoparticles. Mishra et al. used biotinylated di-tryptophan, a short-conjugated peptide for the one-pot synthesis of stable gold nanoparticles [135]. The NPs generated in this process was of an average size of 4 to $6 \mathrm{~nm}$ and was stabilized by tryptophan dipeptide. In another research, Giese et al. explained the synthesis of AgNPs under electron transfer conditions [136] where Ag+ ions bound by a histidine as the Ag-binding amino acid and a tyrosine as a photo inducible electron donor of the bound peptide.

The application of a multidomain peptide (DOPA) for single-step, size-controlled synthesis of biofunctionalized AuNPs was described by Tekinay and coworkers [137]. The size-controlled synthesis of AuNPs was possible due to the presence of 3,4-dihydroxy-L-phenylalanine (L-DOPA) functional group in the peptide which is reductive in nature. Formation of biofunctionalized AuNPs took place as DOPA coupled its oxidation to the reduction of $\mathrm{Au}$ (III) ions and no additional reagent or reaction was needed. Applications of the microbial proteins (enzymes) to synthesze nanoparticles with varying range of shapes, sizes, and surface chemistry have been reported in the literature. Cholami-Shabami et al. had developed a cell-free viable approach to synthesize gold nanoparticles with the help of NADPH-dependent sulphite reductase enzyme, isolated and purified from Escherichia coli. [141]. These gold nanoparticles found to have strong inhibitory effect against the growth of various human pathogenic fungi [141]. Another interesting approach developed by Kas et al., was the synthesis of nanosilica-supported Ag nanoparticles using biosynthetic protocol [142].

In recent research heterogeneous hybrid nanocatalysts are being developed using the metals in combination with protein and peptides. This technique involves the formation of metal NPs embedded in an enzymatic (protein/peptide) net and the development was done in in situ condition under very mild reaction. One such example is the development of nanocatalyst using the mixture of lipase from Candida antarctica fraction $\mathrm{B}(\mathrm{CAL}-\mathrm{B})$ with a homogeneous aqueous solution of a noble metal salt $\left(\mathrm{Ag}^{+}, \mathrm{Pd}^{2+}\right.$, or $\left.\mathrm{Au}^{3+}\right)$ [143]. This 
Green Peptide-nanomaterials; A Friendly Healing Touch for Skin Wound Regeneration

new hybrid is unique in possessing both the metallic and enzymatic catalytic activities. In this process there was generation of small metal NPs. This process does not require any external reducing agent but exploite the reductive efficacy of the biomacromolecule (biomineralization). This biomacromolecule remains catalytically active even at the end of the synthesis [143]. Based on these strategies an interesting biosynthetic route for cost-effective productions of various metal NPs ( $\mathrm{Pd}, \mathrm{Pt}$, and $\mathrm{Ag}$ ) on the surface of fungal mycelia [144] was reported by Das et al. (2014). When the reduction of metal ions took place by means of this strategy, the size and shape can be varied depending on the type of the metal NPs. For example, "flower"like branched nanoparticles were obtained in the case of $\mathrm{Pd}$ and $\mathrm{Pt}$, while $\mathrm{Ag}$ produced spheroidal nanoparticles [144].

Another useful element of synthesizing precise and highly functionalized metal nanoparticles is the engineered proteins. For example, a small variant of protein A has been used as biotemplate in the onestep synthesis and biofunctionalization of AuNPs [145]. This biotemplate is composed of thiolate ligand capable of interacting with the AuNP surface and controlling the nanoparticle nucleation and growth, thus allowing the nanoparticle size to be finely tuned. Jang et al. (2015) published a work on the synthesis of thin-walled (ca. $40 \mathrm{~nm}$ ) $\mathrm{SnO}_{2}$ nanotubes functionalized with catalytic $\mathrm{Pt}$ and Au nanoparticles via a protein templating route [146]. This strategy helps in developing nanomaterials peptide conjugates with very high surface area-to-volume ratio which ultimately leads to superior catalytic performances $[146,147]$.

\section{Healing of Wounds and Nanoparticles}

\subsection{Process of Healing}

Healing is a complex process composed of a series of continuous as well as overlapping events. The events of healing include haemostasis, inflammation, proliferation, epithelialization, maturation, and remodeling of the wounded tissue [148] (Figure 1).

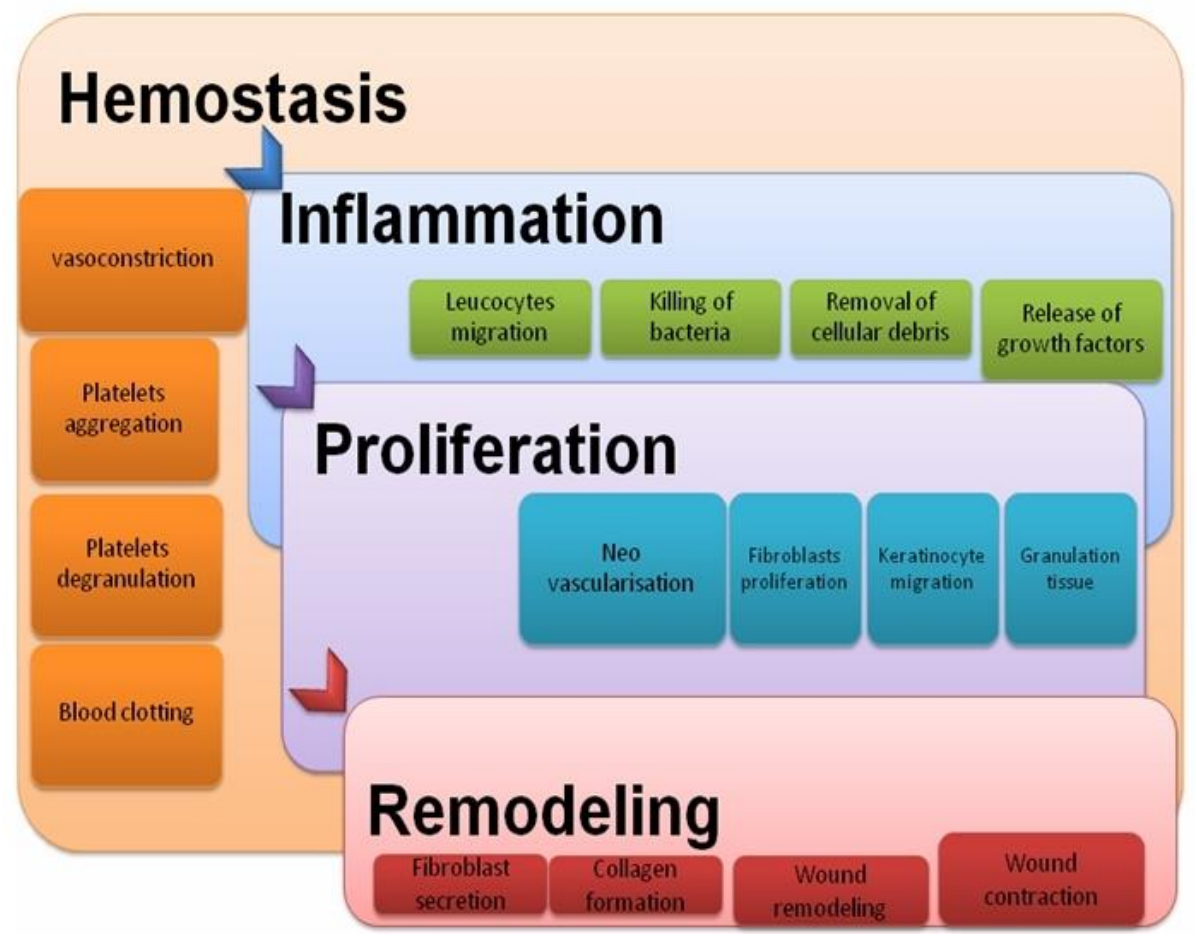

Figure 1: The event of wound healing.

Haemostasis is the event that occurs just after injury. The platelets located in the intravascular space get activated due to the exposure of sub-endothelial collagen leading to the formation of thrombin (23). Platelets play a very important role in the process of healing. At first there is activation of the coagulation 
cascade. After which the formation of the fibrin fibres takes place. These fibres act as scaffolding for other cells that enter the wound later. Just after this the complement system joins the process of healing after which platelet degranulation occurs. Wound healing is a complex process which involves a series of components. Such components include cytokines, growth factors, and vasoactive substances from the platelet a-granules, platelet-derived growth factor (PDGF), transforming growth factor- $\beta$ (TGF- $\beta$ ), fibroblast growth factor (FGF), endothelial growth factor (EGF), platelet-derived angiogenesis factor, serotonin, bradykinin, platelet-activating factor, thromboxane A2, platelet factor IV, prostaglandins, and histamine. The early events during the healing are initiated by these set of components [148,149].

The first event is inflammation which starts just after the injury at the site of wounding and lasts for up to 6 days [150]. During inflammation the platelets release different growth factors which then diffuse into the surrounding tissues of the wound. These factors then chemotactically attract the inflammatory cells at that site. The first inflammatory cells that enter the wound are neutrophils and then monocytes. The activation of the inflammatory cells takes place by local mediators. A number of lysosomal enzymes are released by the activated neutrophils. Few such enzymes are elastase, neutral proteases, and collagenase. These enzymes proteolytically destroy the damaged components of extracellular matrix [150]. Monocytes play important role in host defense by acquiring the phenotype of macrophages [150]. In this phase of proliferation, the formation of the extra cellular matrix (ECM) starts with the beginning of angiogenesis. Fibroblasts and endothelial cells are the primary cells to take part in this process. The proliferation starts in response of the components released at the site of wounding. Growth factors, cytokines are responsible for the induction of proliferation. These components are released from macrophages, platelets and mesenchymal cells. The fibroblast activation and proliferation is actually induced by the PDGF, FGF, and EGF [151] after its arrival at the site of injury. Fibroblasts show predominant activities like migration and proliferation at 2-3 days of injury, after which collagen and glycosaminoglycans get released from this fibroblast cells. The release of these components is actually the response to macrophage-released growth factors, hypoxia and by-products of anaerobic metabolism. In combination of collagen and fibronectin new ECM gets formed. The formation of ECM is essential for the development of granulation tissue. This granulation tissue in turn fills the wound [148].

Fibroblast proliferation is accompanied by the phenomenon called Angiogenesis. In this process the nutrients and healing factors enter at the wound space. Angiogenesis is also important for the growth and development of the granulation tissue. The principle regulators of angiogenesis are FGF and vascular endothelial growth factor (VEGF). The first factor is released by the damaged endothelial cells and macrophages whereas the other is released by the keratinocytes and macrophages [148]. The maturation phase actually begins after three weeks of injury and it may take up to two years to be completed [152]. In the injured skin the arrangement of newly formed collagen fibres show random and disorganized orientation. Thus, the remodeling of the collagen fibers is necessary to help in organizing the collagen fiber into its lattice structure. This structural organization gradually increases the tensile strength of the scar tissue. However, the recovery never exceeds 80 percent of the strength of intact skin. A balance between the synthesis and degradation of collagen is required for the remodeling of the ECM. Both synthesis and degradation are enzyme induced processes. Different enzymes take part in this process like matrix metalloproteinases (MMPs), neutrophil released elastase and gelatinase, collagenases and stromelysins [153]. A Wound is said to be chronic if not healed within three months after injury. There are differences between the chronic and acute wound. A balance between the production and degradation of molecules responsible for healing is present in acute wounds but absent in chronic wound where the rate of degradation is high. The chronic wound bed compared to acute one has a higher concentration of proteases (such as MMPs) [154] but lower levels of growth factors and cytokines [155] when compared to acute wounds. In chronic wound the proteolytic activity is high and prolonged which may lead to the degradation of growth factors and thus the wound remains in the inflammatory stage for a longer period of time [156]. 


\subsection{Nanoparticles in Healing Wounds}

Nanotechnology is the most growing and challenging field of research in modern science as formulated nanomaterials play crucial role in our daily life. Different types of nanomaterials have been incorporated in diverse applications of healthcare machinery and biomedicine. Varieties of products have been emerged due to the upscale research in nanotechnology creating a scope of application of these in the science of wound healing and tissue regeneration [157]. Silver is the most common anti-bacterial agent that is very frequently used for treating burns, open wounds, and other chronic wounds as well [158]. There are a number of evidences showing the role of AgNPs and their anti-microbial activity [159-164]. Topical administration of AgNPs is more efficient as an antimicrobial agent when compared to other test formulations. AgNPs can interact with the sulfur and phosphorus containing proteins of bacterial cell membranes even at a very low concentration and thus control bacterial colony. The particles have effective antimicrobial activity against Bacillus subtilis, E. coli, and $S$. Aureus and other skin pathogens $[165,166]$. In vivo studies revealed that silver nanoparticles can promote the healing process directly by reducing the cytokinemodulated inflammation. Silver has the ability to induce neutrophil apoptosis and to decrease the MMPs activity with negative modulation on TGF- $\beta$ enhancing overall acceleration of wound healing with a reduction in hypertrophic scarring [167]. Silver ions can also promote the rate of proliferation and migration of keratinocytes and stimulate the differentiation of fibroblasts into myofibroblasts which in turn promote wound contraction [168]. As the use of any metal in any form has the chance of carrying possible side effects one must investigate the biosafety of that compound before considering it in therapeutic application. In case of silver nanoparticle, it has an acceptable rate of biocompatibility $[169,170]$.

According to Leu et al. (2012) gold nanoparticle (AuNPs) is one of the promising biologically active nanomaterials [171] when conjugated with antioxidants rich compounds (epigallocatechin gallate and alipoic acid) to accelerate wound healing in mice [171]. The triggering properties of anti-oxidant with the AuNPs actually promote the accelerated healing after its topical application on both normal and diabetic wounds [172] Copper $(\mathrm{Cu})$, titanium Dioxide $\left(\mathrm{TiO}_{2}\right)$ and zinc Oxide $(\mathrm{ZnO})$ nanoparticles are also effective against E. coli and S. aureus, and other skin pathogens that cause diabetic wound, foot-ulcer and burn wound infections [173-175]. Two most widely used nanoparticles in cosmetic and pharmaceutical industry are $\mathrm{TiO}_{2}$ and $\mathrm{ZnO}$ as they act as UV protectors as well as wound healer [176]. $\mathrm{TiO}_{2}$ nanoparticles synthesized using Origanum vulgare when investigated for healing efficacy on excision wound model, it revealed significant wound healing activity [177].

Most modern tissue engineering techniques involve nano-fibers and nanoparticles for regeneration or repairing of wounds. This technique involves the construction of biocompatible scaffold combined with bioactive molecules. Electro spun nano-fibers are provided with large surface area and porosity with permeability for oxygen and water to make it efficient for protection of the wound from bacterial infection. These properties of electro spun nano-fibers make them suitable for dressing of wounds like diabetic ulcers and burns. Other biomaterials like Chitosan, Collagen, and Poly lactic acid have also been tested on animal wound models, revealed an increased rate of wound contraction and epithelialization [178]. These biomaterials also found to possess good anti-bacterial activity [179]. Chong et al. proposed a cost effective nanofibrous scaffold consisting of electro spun onto polyurethane dressing for healing of dermal wounds $[180,181]$. Tissue engineered nanoparticles can be found as polymer and carbon-matrix nano composites [182]. Nanocarriers, nanosensors are mainly developed by using carbon nano tubes. These nanomaterials are useful in tissue engineering as they promote wound healing [183]. NO (Nitric oxide) is a powerful free radical and found to work as a wound healing agent. Its activity is observed in the inflammatory as well as in the proliferative phase of healing. Evidences showed that the antibacterial activities of the NOnanoparticles enhance the wound healing [184-186]. Gold nanodots fabricated with antimicrobial peptides found to possess inhibitory effect on the growth of multi drug-resistant bacteria and thus promote wound healing in animal model [187]. Curcumin is known for its anti-biotic, anti-viral and antioxidant properties 
$[188,189]$. Investigation revealed that the delivery of Curcumin using nanomaterials as vehicles in wound healing had yielded good result.

\section{Possible Mechanism of Action of Green Peptide Nanomaterial in Wound Regeneration}

Infection during the time of healing is the most potent interference causing delay in wound closure and exacerbating the tissue damage. Wound care is a serious healthcare concern as it is often found that the process of healing become complicated due to prolonged inflammation and bacterial infection. Appropriate antimicrobial therapy of the wound includes controlling of colonization and proliferation of the pathogens, including multidrug-resistant organisms [190.191]. Bioactive peptides are important in therapeutics as they promote wound healing. They not only prevent microbial infection but also induce the growth of new blood vessels and epithelial tissue. They promote different physiological processes required for fast healing like homeostasis, defense, growth, differentiation, and senescence. The delivery of green-peptide therapy via nanoparticles offers great potential advantages in modulating the healing process in a far better way.

Now if the release of the bioactive compound can be done in a more precise way then it will decrease the number of doses required to achieve the desired clinical effect. Thus, there will be lesser chance of development of antibiotic resistance and physiological toxicity. The determinants for the in vivo delivery of the peptide nanoparticles are the physicochemical properties of nanoparticulate drug delivery systems (size, surface charge, and nature etc.). It is a well-known fact that $20-200 \mathrm{~nm}$ particles are suitable for delivery of therapeutics. The major disadvantage of larger particles is that they can be uptaken quickly by the reticuloendothelial system followed by rapid clearance from circulation. However, in case of smaller particles they tend to cross the fenestration in the hepatic sinusoidal endothelium, resulting hepatic accumulation.

On the basis of the requirement several options are available for the improvement of the quality, selectivity, durability, and safety of the green peptides. For example, the functional and immunological properties can be improved by partial hydrolysis of the peptide molecules as the resulting hydrolysate is more useful as pharmaceutical ingredient [192,193]. Bioactive peptides can be computationally modeled, genetically manipulated, and expressed in different systems to serve a wide range of practical purpose. Other than antimicrobial efficacy several other intriguing functions like opioid, antithrombotic, immunomodulatory, and antihypertensive are also emerging with the advancement of research [193-195] as a result of which the peptides are becoming more suitable for accelerated wound recovery. Thus, it can be said that these bioactive peptides are the natural alternatives with potential to be used in a variety of applications [194,195]. The numbers of innovative nano therapies in the field of wound healing are increasing day by day and most of them are currently under clinical investigation. Different nanoscale strategies have been developed to target different phases of wound recovery. The two major categories of nanomaterials used in wound healing are (1) nanomaterials that exhibit intrinsic properties beneficial for wound treatment and (2) nanomaterials employed as delivery vehicles for therapeutic agents $(23,197)$ such as green peptides. Chen et al. used gold nanodots functionalized using antimicrobial peptides in rodent wound model to inhibit the growth of drug-resistant bacteria and promote healing (198). The functionalization was done by selfassembly of cyclic lipopeptide surfactin (SFT) on gold nanodots by hydrophobic interaction with 1dodecanethiol (DT) molecules that cap the gold nanodots. This functionalized nanoparticle was found to hold higher antibacterial potency against Gram-negative and Gram-positive bacteria than free SFT. The enhanced inhibitory effect of the compound was higher in comparison to the peptidic antibiotic alone was because of the ability of the designed nanoparticles to disintegrate the bacterial membrane. Gold nanoparticles (AuNPs) combined with antioxidants like epigallocatechinegallate (EGCG) and a-lipoic acid (ALA) was tested on diabetic ulcer wounds. These nanoparticles showed accelerated healing by the modulation of inflammation and angiogenesis. The application of this composition on the wounds also stimulates an increase in the skin absorptivity of this nanoscale mixture. The majority of these nanoparticle carriers have been used for the delivery of therapeutic agents with antibacterial properties and thus the antimicrobial peptides derived from plants are so crucial to identify and develop. 


\section{Conclusion}

Faster healing by means of inhibiting microbial infection with accelerated wound closure without scar formation can only be achieved by implementation of novel strategies. Nanotechnology is the field that is growing constantly and thus also revolutionizing the therapeutics. Treatment and management of wound care is getting better due to the incorporation of the novel solutions using biomaterials and theranostic nanoparticles. Thus, it can be said that the Nanotechnology-based therapy is the possible next-generation therapy for the advancement of wound healing to cure chronic wounds. Nowadays, the effectiveness of the antibiotics is declining, and thus antimicrobial peptides have become one of the considerable interests of the scientists of today. These peptides are proved to have potential as the broad-spectrum antibiotics thus have usefulness as novel therapeutic agents. But for the accurate application it is important to know the behavior and toxicity of these nanoscale products in the human body and the real hurdle is to gather enough information regarding this. Moreover, we need to develop better synthetic tools along with analytical methods which will allow us to apply the nanotechnology-based approaches to the clinic in real situations. We also need to put great efforts to arm chronic wound therapies by making them more site-specific, we also need to increase the target efficiency of these nanoproducts so that undesirable events can easily be avoided. Approach of research also need to be designed in such a way that it can help to overcome the interferences for the nanosystems to perform their biological functions in the tissues.

\section{Acknowledgement}

The authors acknowledge the University of Kalyani and Swami Vivekananda Scholarship scheme, West Bengal, India for the financial assistance for submission of the review.

\section{How to Cite this Article:}

D. Nath, P. Banerjee, A. Ray, and B. Bairagi, “Green Peptide-nanomaterials; A Friendly Healing Touch for Skin Wound Regeneration”, Adv. Nan. Res., vol. 2, no. 1, pp. 14-31, Mar. 2019. DOI: 10.21467/anr.2.1.14-31

\section{References}

[1] Zhou, W.; Gao, X.; Liu, D.; Chen, X. Gold Nanoparticles for in Vitro Diagnostics. Chem. Rev. 2015, 115, 10575-10636.

[2] DaCosta, M.V.; Doughan, S.; Han, Y.; Krull, U.J. Lanthanide upconversion nanoparticles and applications in bioassays and bioimaging: A review. Anal. Chim. Act. 2014, 832, 1-33.

[3] Shi, D.; Sadat, M.E.; Dunn, A.W.; Mast, D.B. Photo-fluorescent and magnetic properties of iron oxide nanoparticles for biomedical applications. Nanoscale 2015, 7, 8209-8232.

[4] Goldberg, M.S. Immunoengineering: How nanotechnology can enhance cancer immunotherapy. Cell 2015, 161, $201-204$.

[5] MubarakAli, D.; Gopinath, V.; Rameshbabu, N.; Thajuddin, N. Synthesis and characterization of CdS nanoparticles using Cphycoerythrin from the marine cyanobacteria. Mater. Lett. 2012, 74, 8-11.

[6] Saldan, I.; Semenyuk, Y.; Marchuk, I.; Reshetnyak, O. Chemical synthesis and application of palladium nanoparticles. J. Mat. Sci. 2015, 50, 2337-2354.

[7] Gutiérrez, L.; Costo, R.; Grüttner, C.; Westphal, F.; Gehrke, N.; Heinke, D.; Fornara, A.; Pankhurst, Q.A.; Johansson, C.; Veintemillas-Verdaguer, S.; et al. Synthesis methods to prepare single- and multi-core iron oxide nanoparticles for biomedical applications. Dalton Trans. 2015, 44, 2943-2952.

[8] Shervani, Z.; Yamamoto, Y. Carbohydrate-directed synthesis of silver and gold nanoparticles: Effect of the structure of carbohydrates and reducing agents on the size and morphology of the composites. Carbohydr. Res. 2011, 346, 651-658.

[9] Yokota, S.; Kitaoka, T.; Opietnik, M.; Rosenau, T.; Wariishi, H. Synthesis of gold nanoparticles for in situ conjugation with structural carbohydrates. Angew. Chem. Int. Ed. 2008, 47, 9866-9869.

[10] Engelbrekt, C.; Sørensen, K.H.; Zhang, J.; Welinder, A.C.; Jensen, P.S.; Ulstrup, J. Green synthesis of gold nanoparticles with starchglucose and application in bioelectrochemistry. J. Mater. Chem. 2009, 19, 7839-7847.

[11] Care, A.; Bergquist, P.L.; Sunna, A. Solid-binding peptides: Smart tools for nanobiotechnology. Trends Biotechnol. 2015, 33, 259268.

[12] Tan, Y.N.; Lee, J.Y.;Wang, D.I.C. Uncovering the design rules for peptide synthesis of metal nanoparticles. J. Am. Chem. Soc. 2010, $132,5677-5686$.

[13] Filice, M.; Marciello, M.; Morales, M.P.; Palomo, J.M. Synthesis of heterogeneous enzyme-metal nanoparticle biohybrids in aqueous media and their applications in C-C bond formation and tandem catalysis. Chem. Commun. 2013, 49, 6876-6878.

[14] Mittal, A.K.; Chisti, Y.; Banerjee, U.C. Synthesis of metallic nanoparticles using plant extracts. Biotechnol. Adv. 2013, 31, 346-356.

[15] Chinnadayyala, S.R.; Santhosh, M.; Singh, N.K.; Goswami, P. Alcohol oxidase protein mediated in situ synthesized and stabilized gold nanoparticles for developing amperometric alcohol biosensor. Biosen. Bioelec. 2015, 69, 151-161.

[16] Hulkoti, N.I.; Taranath, T.C. Biosynthesis of nanoparticles using microbes-A review. Colloids Surf. B 2014, 121, 474-483. 
Nath et al., Adv. Nan. Res.; Vol. 2 Issue 1, pp: 14-31, 2019

[17] Mashwani, Z.U.R.; Khan, T.; Khan, M.A.; Nadhman, A. Synthesis in plants and plant extracts of silver nanoparticles with potent antimicrobial properties: Current status and future prospects. App. Microb. Biotechnol. 2015, 99, 9923-9934.

[18] Sousa, A.A.; Hassan, S.A.; Knittel, L.L.; Balbo, A.; Aronova, M.A.; Brown, P.H.; Schuck, P.; Leapman, R.D. Biointeractions of ultrasmall glutathione-coated gold nanoparticles: Effect of small size variations. Nanoscale 2016, 8, 6577-6588.

[19] Vlieghe P, Lisowski V, Martinez J, Khrestchatisky M. Synthetic therapeutic peptides: science and market.Drug Discov Today. 2010 15(1-2):40-56.

[20] Seetharam RN: Nanomedicine emerging area of nanotechnology research, curr. Sci. (3) (91) (260), 2006

[21] Sandhiya S, Dkhar SA, Surendiran A: Emerging trends of nanomedicine - an overview. Fundam. Clin. Pharmacol. 2009, 23(3), 263269

[22] Suri SS, Fenniri H, Singh B: Nanotechnology-baseddrugdeliverysystems J. Occup. Med. Toxicol. 2007, 2, 16.

[23] Tocco, I.; Zavan, B.; Bassetto, F.; Vindigni, V. Nanotechnology Based Therapies for Skin Wound Regeneration. J. Nanomater. 2012, 11, 1471-1477.

[24] Wang Z. and Wang G., APD: the antimicrobial peptide database, Nucleic Acids Research, 2004, 32, D590-D592,.

[25] Park I. Y., Cho J. H., Kim K. S., Kim Y.B., Kim M. S., and Kim S. C., Helix stability confers salt resistance upon helical antimicrobial peptides, The Journal of Biological Chemistry, 2004, 279(14), 13896-13901,.

[26] Yamaguchi Y. and Huffaker A., Endogenous peptide elicitors in higher plants. Current Opinion in Plant Biology, 2011,14(4), 351357.

[27] Hancock R. E.W., Peptide antibiotics, The Lancet, 1997, 349(9049), 418-422.

[28] Boman H. G., Innate immunity and the normal microflora, Immunological Reviews, 2000, 173 (1) 5-16,.

[29] H. M.Ward, Disease in Plants, Macmillan, 1901.

[30] Powers J.P. S., Rozek A., and Hancock R. E. W., Structureactivity relationships for the $\beta$-hairpin cationic antimicrobial peptide polyphemusin I, Biochimica et Biophysica Acta: Proteins and Proteomics, 2004,1698( 2), 239-250.

[31] Mu. L, Tang J., Liu H., Shen C., Rong M., Zhang Z., Lai R.. A potential wound-healing-promoting peptide from salamander skin. The faseb journal, 2014; 28 (9): 3919

[32] Cao X,; Wang Y, Wu. C, Li .X,; Yang, Z F, Bian W, Wang S, Song Y, Tang J \& Yang.X.Cathelicidin-OA1, a novel antioxidant peptide identified from an amphibian, accelerates skin wound healing, Scientific Reports 2018, 8, 943

[33] van der Weerden N. L., Hancock R. E.W., and Anderson M. A., Permeabilization of fungal hyphae by the plant defensin NaD1 occurs through a cell wall-dependent process, Journal of Biological Chemistry, 2010, 285 (48),37513-37520.

[34] Nawrot R., Barylski J., Nowicki G., Broniarczyk J., Buchwald W., and Gózdzicka A.J'ozefiak, Plant antimicrobial peptides, Folia Microbiologica, , 2014 , 59 (3),181-196.

[35] Gr"un S., Lindermayr C., Sell S., and Durner J., Nitric oxide and gene regulation in plants, Journal of Experimental Botany, 2006, 57(3), 507-516.

[36] Sitaram N. and Nagaraj R., Interaction of antimicrobial peptides with biological and model membranes: structural and charge requirements for activity, Biochimica et Biophysica Acta: Biomembranes, 1999, 1462 (1-2), 29-54,.

[37] Yokoyama S., Iida Y., Kawasaki Y., Minami Y., Watanabe K., and Yagi F., The chitin-binding capability of Cy-AMP1 from cycad is essential to antifungal activity, Journal of Peptide Science, 2009, 15(7), 492-497.

[38] Selitrennikoff C. P., Antifungal Proteins, Applied and Environmental Microbiology, 2001, 67(7), 2883-2894.

[39] Perez A., Li Q.X., Perez-Romero P. et al., A new class of receptor for herpes simplex virus has heptad repeat motifs that are common to membrane fusion proteins, Journal of Virology, 2005, 79(12) 7419-7430.

[40] Edward W. Robinson J., McDougall B., Tran D., and Selsted M. E., Anti-HIV-1 activity of indolicidin, an antimicrobial peptide from neutrophils, Journal of Leukocyte Biology, 1998, 63(1), 94-100.

[41] Stec B., Plant thionins: the structural perspective, Cellular and Molecular Life Sciences, 2006, 63(12),1370-1385.

[42] Pelegrini P. B., Quirino B. F., andFranco O. L., Plant cyclotides: an unusual class of defense compounds, Peptides, 2007, 28(7), 14751481.

[43] Stotz H. U., Thomson J. G., and Wang Y., Plant defensins: defense, development and application, Plant Signaling \& Behavior, 2009, 4(11), pp. 1010-1012.

[44] Schwarze SR, Ho A, Vocero-Akbani A, Dowdy SF. In Vivo Protein Transduction: Delivery of a Biologically Active Protein into the Mouse. Science. 1999; 285(5433):1569-1572.

[45] Torchilin V.P., Rammohan R., Weissig V., Levchenko T.S. TAT peptide on the surface of liposomes affords their efficient intracellular delivery even at low temperature and in the presence of metabolic inhibitors. Proceedings of the National Academy of Sciences. 2001; 98(15):8786-8791.

[46] Frankel. A.D., Pabo C.O. Cellular uptake of the tat protein from human immunodeficiency virus. Cell. 1988; 55(6):1189-1193.

[47] Green. M., Loewenstein. P.M. Autonomous functional domains of chemically synthesized human immunodeficiency virus tat transactivator protein. Cell. 1988; 55(6):1179-1188.

[48] Vivès. E., Brodin. P., Lebleu. B. A Truncated HIV-1 Tat Protein Basic Domain Rapidly Translocates through the Plasma Membrane and Accumulates in the Cell Nucleus. Journal of Biological Chemistry. 1997; 272(25):16010-16017.

[49] Derossi. D., Joliot. A.H., Chassaing. G., Prochiantz. A. The third helix of the Antennapedia homeodomain translocates through biological membranes. Journal of Biological Chemistry. 1994; 269(14):10444-10450.

[50] Elliott. G., O'Hare. P. Intercellular Trafficking and Protein Delivery by a Herpesvirus Structural Protein. Cell. 1997; 88(2):223-233.

[51] Hou. K.K., Pan. H., Lanza. G.M., Wickline. S.A. Melittin derived peptides for nanoparticle based siRNA transfection. Biomaterials. 2013; 34(12):3110-3119.

[52] Gao. S, Simon. M.J., Hue. C.D., Morrison. B., Banta. S. An Unusual Cell Penetrating Peptide Identified Using a Plasmid DisplayBased Functional Selection Platform. ACS Chemical Biology. 2011; 6(5):484-491.

[53] Milletti. F. Cell-penetrating peptides: classes, origin, and current landscape. Drug Discovery Today. 2012; 17(15-16):850-860.

[54] Bailey. P., Wilce. J. Venom as a source of useful biologically active molecules. Emergency Medicine. 2001; 13(1):28-36.

[55] Lewis. R.J., Garcia. M.L. Therapeutic potential of venom peptides. Nature Reviews Drug Discovery. 2003; 2(10):790-802. 
[56] Dutertre. S., Lewis. R.J. Use of Venom Peptides to Probe Ion Channel Structure and Function. Journal of Biological Chemistry. 2010; 285(18):13315-13320.

[57] Andersson. D.I, Hughes. D. Persistence of antibiotic resistance in bacterial populations. FEMS Microbiology Reviews. 2011; 35(5):901-911.

[58] Bush. K., Courvalin. P., Dantas. G., Davies. J., Eisenstein. B., Huovinen. P., Zgurskaya H.I. Tackling antibiotic resistance. Nature Reviews Microbiology. 2011; 9(12):894-896.

[59] Hancock. R.E.W, Sahl. H.G. Antimicrobial and host-defense peptides as new anti-infective therapeutic strategies. Nature Biotechnology. 2006; 24(12):1551-1557.

[60] Nguyen L.T., Haney E.F., Vogel H.J. The expanding scope of antimicrobial peptide structures and their modes of action. Trends in Biotechnology. 2011; 29(9):464-472.

[61] Zasloff M. Antimicrobial Peptides in Health and Disease. New England Journal of Medicine. 2002; 347(15):1199-1200.

[62] Bradshaw J. Cationic antimicrobial peptides: issues for potential clinical use. BioDrugs: Clinical Immunotherapeutics, Biopharmaceuticals and Gene Therapy. 2003; 17(4):233-240.

[63] Jallouk A.P., Moley. K.H., Omurtag. K., Hu. G., Lanza G.M., Wickline S.A., Hood J.L. Nanoparticle Incorporation of Melittin Reduces Sperm and Vaginal Epithelium Cytotoxicity. PLoS ONE. 2014; 9(4):95411.

[64] Hood J.L, Jallouk A.P., Campbell N, Ratner L, Wickline S.A. Cytolytic nanoparticles attenuate HIV-1 infectivity. Antiviral Therapy. 2013; 18(1):95-103.

[65] Chereddy K.K, Her C.H, Comune M, Moia C, Lopes A, Porporato P.E., Préat V. PLGA nanoparticles loaded with host defense peptide LL37 promote wound healing. Journal of Controlled Release. 2014; 194:138-147.

[66] Hancock R. E.W., Peptide antibiotics, The Lancet, 1997, 349 (9049), 418-422.

[67] Boman H. G., Innate immunity and the normal microflora, Immunological Reviews, 2000, 173(1), 5-16.

[68] Ward H. M., Disease in Plants, Macmillan, 1901, New york and London, pp309

[69] Powers J.P. S., Rozek A., and Hancock R. E. W., Structureactivity relationships for the $\beta$-hairpin cationic antimicrobial peptide polyphemusin I, Biochimica et Biophysica Acta: Proteins and Proteomics, 2004, 1698(2), 239-250.

[70] Hultmark D., Steiner H., Rasmuson T., and Boman H. G., Insect immunity. Purification and properties of three inducible bactericidal proteins from hemolymph of immunized pupae of Hyalophora cecropia, European Journal of Biochemistry, 1980, 106(1),7-16.

[71] T. C. Mettenleiter, Brief overview on cellular virus receptors, Virus Research, vol. 82, no. 1-2, pp. 3-8, 2002.

[72] van der Weerden N. L., Hancock R. E.W., and Anderson M. A., Permeabilization of fungal hyphae by the plant defensin NaD1 occurs through a cell wall-dependent process, Journal of Biological Chemistry, 2010, 285( 48), 37513-37520.

[73] Nawrot R., Barylski J., Nowicki G., Broniarczyk J., Buchwald W., and Go'zdzicka-J’ozefiak A., Plant antimicrobial peptides, Folia Microbiologica, 2014, 59(3), 181-196,.

[74] Bahar A. A. and Ren D., Antimicrobial peptides, Pharmaceuticals, 2013, 6(12), 1543-1575.

[75] Jenssen H., Hamill P., and Hancock R. E. W., Peptide antimicrobial agents, Clinical Microbiology Reviews, 2006, 19(3), 491-511.

[76] Liu Y., Gong W., Huang C. C., Herr W., and Cheng X., Crystal structure of the conserved core of the herpes simplex virus transcriptional regulatory protein VP16, Genes and Development, 1999, 13(13), 1692-1703.

[77] Pelegrini P. B., Del Sarto R. P., Silva O. N., Franco O. L., and Grossi-De-Sa M. F., Antibacterial peptides from plants: what they are and how they probably work, Biochemistry Research International, 2011, 2011, 250349, .

[78] Sinha S., Cheshenko N., Lehrer R. I., and Herold B. C., NP- 1, a rabbit $\alpha$-defensin, prevents the entry and intercellular spread of herpes simplex virus type 2, Antimicrobial Agents and Chemotherapy, 2003, 47(2), 494-500.

[79] Wachinger M., Kleinschmidt A., Winder D. et al., Antimicrobial peptidesmelittin and cecropin inhibit replication of human immunodeficiency virus 1 by suppressing viral gene expression, Journal of General Virology, 1998, 79(4), 731-740.

[80] Laquerre S., Argnani R., Anderson D. B., Zucchini S., Manservigi R., and Glorioso J. C., Heparan sulfate proteoglycan binding by herpes simplex virus type 1 glycoproteins $\mathrm{B}$ and $\mathrm{C}$, which differ in their contributions to virus attachment, penetration, and cell-tocell spread, Journal of Virology, 1998, 72 (7), 6119-6130.

[81] Sitaram N. and Nagaraj R., Interaction of antimicrobial peptides with biological and model membranes: structural and charge requirements for activity, Biochimica et Biophysica Acta: Biomembranes, 1999, 1462(1-2), 29-54.

[82] Yokoyama S., lida Y., Kawasaki Y., Minami Y., Watanabe K., and Yagi F., The chitin-binding capability of Cy-AMP1 from cycad is essential to antifungal activity, Journal of Peptide Science, 2009, 15(7), 492-497.

[83] Selitrennikoff C. P., Antifungal Proteins, Applied and Environmental Microbiology, 2001, 67 (7), $2883-2894$.

[84] Perez A.,. Li Q.X, Perez-Romero P.et al., A new class of receptor for herpes simplex virus has heptad repeat motifs that are common to membrane fusion proteins, Journal of Virology, 2005, 79(12),7419-7430.

[85] Edward W. Robinson Jr., McDougall B., Tran D., and Selsted M. E., Anti-HIV-1 activity of indolicidin, an antimicrobial peptide from neutrophils, Journal of Leukocyte Biology, 1998, 63(1), 94-100.

[86] Stec B., Plant thionins: the structural perspective, Cellular and Molecular Life Sciences, 2006, 63(12), 1370-1385.

[87] Pelegrini P. B., Quirino B. F., and Franco O. L., Plant cyclotides: an unusual class of defense compounds, Peptides, 2007, 289(7),1475-1481.

[88] Stotz H. U., Thomson J. G., and Wang Y., Plant defensins: defense, development and application, Plant Signaling \& Behavior, 2009, 4(11) 1010-1012.

[89] Fernandez-de Caleya R., Gonzalez-Pascual B., Garc'ia- Olmedo F., and Carbonero P., Susceptibility of phytopathogenic bacteria to wheat purothionins in vitro, Applied Microbiology, 1972, 23 (5), 998-1000.

[90] Liu Y., Luo J., Xu C.et al., Purification, characterization, and molecular cloning of the gene of a seed-specific antimicrobial protein from pokeweed, Plant Physiology, 2000, 122(4), 1015-1024.

[91] Tailor R. H., Acland D. P., Attenborough S. et al., A novel family of small cysteine-rich antimicrobial peptides from seed of Impatiens balsamina is derived from a single precursor protein, The Journal of Biological Chemistry, 1997, 272 (39) 24480-24487.

[92] Palumbo D, Iannaccone M, Porta A., and Capparelli R. Experimental antibacterial therapy with puroindolines, lactoferrin and lysozyme in Listeria monocytogenes-infected mice, Microbes and Infection, 2010, 12 (7), 538-545. 
[93] Marcus J. P., Green J. L., Goulter K. C., and Manners J.M., A family of antimicrobial peptides is produced by processing of a 7S globulin protein in Macadamia integrifolia kernels, Plant Journal, 1999, 19( 6), 699-710.

[94] Terras F.R.G., Eggermont K., Kovaleva V. et al., Small cysteinerich antifungal proteins from radish: their role in host defense, The Plant Cell, 1995, 7(5), 573-588,

[95] Zottich U., Da Cunha M., Carvalho A. O. et al., Purification, biochemical characterization and antifungal activity of a new lipid transfer protein (LTP) from Coffea canephora seeds with $\alpha$-amylase inhibitor properties, Biochimica et Biophysica Acta: General Subjects, 2011, 1810(4), 375-383.

[96] Remuzgo C., Oewel T. S., Daffre S. et al., Chemical synthesis, structure-activity relationship, and properties of shepherin I: a fungicidal peptide enriched in glycine-glycine-histidine motifs, Amino Acids, 2014, 46(11), 2573-2586.

[97] Berrocal-Lobo M., Segura A., Moreno M., L'opez G., Garc'ia- Olmedo F., and Molina A., Snakin-2, an antimicrobial peptide from potato whose gene is locally induced by wounding and responds to pathogen infection, Plant Physiology, 2002, 128( 3), 951-961.

[98] Fujimura M., Minami Y., Watanabe K., and Tadera K., Purification, characterization, and sequencing of a novel type of antimicrobial peptides, Fa-AMP1 and Fa-AMP2, from seeds of buckwheat (Fagopyrum esculentum Moench.), Bioscience, Biotechnology and Biochemistry, 2003,67(8), 1636-1642.

[99] Segura A., Moreno M., Molina A., and Garc'ia-Ol medo F., Novel defensin subfamily from spinach (Spinacia oleracea), FEBS Letters, 1998, 435( 2-3), 159-162.

[100] Wong J. H.and Ng T. B., Lunatusin, a trypsin-stable antimicrobial peptide from lima beans (Phaseolus lunatus L.), Peptides, 2005, 26(11), 2086-2092.

[101] Jack H. W. and Tzi B. N., Vulgarinin, a broad-spectrum antifungal peptide from haricot beans (Phaseolus vulgaris), International Journal of Biochemistry and Cell Biology, 2005, 37(8), 1626-1632.

[102] Sharma S., Verma H. N., and Sharma N. K., Cationic bioactive peptide from the seeds of benincasa hispida, International Journal of Peptides, 2014, Article ID 156060, 12 pages.

[103] Ye X. Y, Ng T. B., and Rao P. F., Cicerin and arietin, novel chickpea peptides with different antifungal potencies, Peptides, 2002, 23(5), 817-822.

[104] Chan Y. S., Wong J. H., Fang E. F., Pan W. L., and Ng T. B., An antifungal peptide from Phaseolus vulgaris cv. brown kidney bean, Acta Biochim Biophys Sinica, 2012, 44(4), 307-315.

[105] Wu X., Sun J., Zhang G., Wang H., and Ng T. B., An antifungal defensin from Phaseolus vulgaris cv. "Cloud Bean,” Phytomedicine, 2011,18( 2-3), 104-109.

[106] Thomson A. B. R., Keelan M., Thiesen A., Clandinin M. T., Ropeleski M., and Wild G. E., Small bowel review: normal physiology part 1, Digestive Diseases and Sciences, 2001, 46(12), 2567-2587.

[107] ordegen P. H“, Cabaret J., Hertzberg H., Langhans W., and Maurer V., In vitro screening of six anthelmintic plant products against larval Haemonchus contortus with a modified methylthiazolyl-tetrazoliumreduction assay, Journal of Ethnopharmacology, 2006, 108(1), 85-89.

[108] Zasloff M., Magainins, a class of antimicrobial peptides from Xenopus skin: isolation, characterization of two active forms, and partial cDNA sequence of a precursor, Proceedings of the National Academy of Sciences of the United States of America, 1987, 84(15),5449-5453.

[109] Park Y., Jang S.H., Lee D. G., and Hahm K.S., Antinematodal effect of antimicrobial peptide, PMAP-23, isolated fromporcine myeloid against Caenorhabditis elegans, Journal of Peptide Science, 2004,10(5), 304-311.

[110] Tagboto S. and Townson S., Antiparasitic properties of medicinal plants and other naturally occurring products, Advances in Parasitology, 2001,50, 199-295.

[111] Stepek G., Buttle D. J., Duce I. R., Lowe A., and Behnke J. M., Assessment of the anthelmintic effect of natural plant cysteine proteinases against the gastrointestinal nematode, Heligmosomoides polygyrus, in vitro, Parasitology, 2005, 130(2), $203-211$.

[112] Lay F. T. and Anderson M. A., Defensins - components of the innate immune system in plants, Current Protein \& Peptide Science, 2005, 6(1), 85-101.

[113] Ganz T., Selsted M. E., Szklarek D. et al., Defensins. Natural peptide antibiotics of human neutrophils, The Journal of Clinical Investigation, 1985, 76(4), 1427-1435.

[114] Patil A., Hughes A. L., and Zhang G., Rapid evolution and diversification of mammalian $\alpha$-defensins as revealed by comparative analysis of rodent and primate genes, Physiological Genomics, 2005, 20,1-11.

[115] Tian C., Gao B., Fang Q., Ye G., and Zhu S., Antimicrobial peptide-like genes in Nasonia vitripennis: a genomic perspective, BMC Genomics, 2010, 11(1), article 187.

[116] Saito T., Kawabata S. I., Shigenaga T. et al., A novel big defensin identified in horseshoe crab hemocytes: isolation, amino acid sequence, and antibacterial activity, Journal of Biochemistry, 1995, 117 (5),1131-1137.

[117] Thomma B. P. H. J., Cammue B. P. A., and Thevissen K., Plant defensins, Planta, 2002, 216 (2),193-202.

[118] Galg'oczy L., Kov'acs L., and V'agv"olgyi C., Defensin-like antifungal proteins secreted by filamentous fungi, in Current Research, Technology and Education Topics in Applied Microbiology and Microbial Technology, pp. 550-559, 2010.

[119] Games P. D., dos Santos I. S., Mello E. O. et al., Isolation, characterization and cloning of a cDNA encoding a new antifungal defensin from Phaseolus vulgaris L. seeds, Peptides, 2008, 29(12),2090-2100.

[120] Broekaert W. F., Cammue B. P. A., de Bolle M. F. C., Thevissen K., de Samblanx G. W., and Osborn R. W., Antimicrobial peptides from plants, Critical Reviews in Plant Sciences, 1997, 16 (3), 297-323.

[121] Osborn R. W., De Samblanx G. W., Thevissen K. et al., Isolation and characterisation of plant defensins from seeds of Asteraceae, Fabaceae, Hippocastanaceae and Saxifragaceae, FEBS Letters, 1995, 368(2), 257-262.

[122] Garc'1a-Olmedo F., Molina Fern’andez A., Alamillo J. M., and Rodriguez Palenzuela P, Plant defence peptides, Peptide Science, 1998, 47 (6), 479-491.

[123] Finkina E. I., Shramova E. I., Tagaev A. A., and Ovchinnikova T. V., A novel defensin from the lentil Lens culinaris seeds, Biochemical and Biophysical Research Communications, 2008, 371(4), 860-865. 
[124] Wheeler J. I. and Irving H. R., Plant peptide signaling: an evolutionary adaptation, in Plant Signaling Peptides, pp. 1-23, Springer, 2012.

[125] Billington T., Pharmawati M., and Gehring C. A., Isolation and immunoaffinity purification of biologically active plant natriuretic peptide, Biochemical and Biophysical Research Communications, vol. 235, no. 3, pp. 722-725, 1997.

[126] Maryani M. M., Bradley G., Cahill D. M., and Gehring C. A., Natriuretic peptides and immunoreactants modify osmoticum-dependent volume changes in Solanum tuberosum L. mesophyll cell protoplasts, Plant Science, 2001, 161(3), 443-452.

[127] Rafudeen S., Gxaba G., Makgoke G. et al., A role for plant natriuretic peptide immuno-analogues in NaCl- and droughtstress responses, Physiologia Plantarum, 2003, 119(4), 554- 562.

[128] Pharmawati M., Billington T., and Gehring C. A., Stomatal guard cell responses to kinetin and natriuretic peptides are cGMPdependent, Cellular and Molecular Life Sciences, 1998, 54( 3), 272-276.

[129] Matsubayashi Y., Ogawa M., Morita A., and Sakagami Y., An LRR receptor kinase involved in perception of a peptide plant hormone, phytosulfokine, Science, 2002, 296(5572),1470- 1472.

[130] Pearce G., Munske G., Yamaguchi Y., and Ryan C. A., Structure-activity studies of GmSubPep, a soybean peptide defense signal derived from an extracellular protease, Peptides, 2010, 31(12), 2159-2164.

[131] Yu L., Moshelion M., and Moran N., Extracellular protons inhibit the activity of inward-rectifying potassium channels in themotor cells of Samanea saman pulvini, Plant Physiology, 2001, 127(3),1310-1322.

[132] Fletcher J. C., Signaling of cell fate decisions by CLAVATA3 in Arabidopsis shoot meristems, Science, 1999, 283(5409),1911-1914

[133] Ogawa M., Shinohara H., Sakagami Y., and Matsubayash Y., Arabidopsis CLV3 peptide directly binds CLV1 ectodomain, Science, 2008, 319(5861), 294.

[134] Strabala T. J., O’Donnell P. J., Smit A.M. et al., Gain-offunction phenotypes of many CLAVATA3/ESR genes, including four new family members, correlate with tandem variations in the conserved CLAVATA3/ESR domain, Plant Physiology, 2006, 140( 4),13311344 ,

[135] Mishra, N.K.; Kumar, V.; Joshi, K.B. Fabrication of gold nanoparticles on biotin-ditryptophan scaffold for plausible biomedical applications. RSC Adv. 2015, 5, 64387-64394.

[136] Kracht, S.; Messerer, M.; Lang, M.; Eckhardt, S.; Lauz, M.; Grobty, B.; Fromm, K.M.; Giese, B. Electron Transfer in Peptides: On the Formation of Silver Nanoparticles. Angew. Chem. Int. Ed. 2015, 54, 2912-2916.

[137] Gulsuner, H.U.; Ceylan, H.; Guler, M.O.; Tekinay, A.B. Multi-domain short peptide molecules for in situ synthesis and biofunctionalization of gold nanoparticles for integrin-targeted cell uptake. ACS Appl. Mater. Interfaces 2015, 7, 10677-10683.

[138] Belser, K.; Slenters, T.V.; Ofumbidzai, C.; Upert, G.; Mirolo, L.; Fromm, K.M.; Wennermers, H. Silver nanoparticle formation in different sizes induced by peptides identified within split-and-mix libraries. Angew. Chem. Int. Ed. 2009, 48, 3661-3664.

[139] Tomizaki, K.Y.; Kubo, S.; Ahn, S.A.; Satake, M.; Imai, T. Biomimetic alignment of zinc oxide nanoparticles along a peptide nanofiber. Langmuir 2012, 28, 13459-13466.

[140] Palomo. J. M. and Filice. M., Biosynthesis of Metal Nanoparticles: Novel Efficient Heterogeneous Nanocatalysts Nanomaterials 2016, 6(5), 84

[141] Gholami-Shabani, M.; Shams-Ghahfarokhi, M.; Gholami-Shabani, Z.; Akbarzadeh, A.; Riazi, G.; Ajdari, S.; Amani, A.; RazzaghiAbyaneh, M. Enzymatic synthesis of gold nanoparticles using sulfite reductase purified from Escherichia coli: A green eco-friendly approach. Process Biochem. 2015, 50, 1076-1085.

[142] Das, S.K.; Khan, M.R.; Guhab, A.K.; Naskar, N. Bio-inspired fabrication of silver nanoparticles on nanostructured silica: Characterization and application as a highly efficient hydrogenation catalyst. Green Chem. 2013, 15, 2548-2557.

[143] Cuenca, T.; Filice, M.; Palomo, J.M. Palladium nanoparticles enzyme aggregate (PANEA) as efficient catalyst for Suzuki-Miyaura reaction in aqueous media. Enzyme Microb. Technol. 2016, 95,242-247.

[144] Das, S.K.; Parandhaman, T.; Pentela, N.; Islam, A.K.M.M.; Mandal, A.B.; Mukherjee, M. Understanding the and catalytic activity of $\mathrm{Pd}, \mathrm{Pt}$, and Ag nanoparticles in hydrogenation and Suzuki coupling reactions at the nano_bio interface. J. Phys. Chem. C 2014, 118, 24623-24632.

[145] Colombo, M.; Mazzucchelli, S.; Collico, V.; Avvakumova, S.; Pandolfi, L.; Corsi, F.; Porta, F.; Prosperi, D. Protein-assisted one-pot synthesis and biofunctionalization of spherical gold nanoparticles for selective targeting of cancer cells. Angew. Chem. Int. Ed. 2012, 51, 9272-9275.

[146] Jang, J.S.; Kim, S.J.; Choi, S.J.; Kim, N.H.; Hakim, M.; Rothschild, A.; Kim, I.D. Thin-walled SnO2 nanotubes functionalized with $\mathrm{Pt}$ and $\mathrm{Au}$ catalysts via the protein templating route and their selective detection of acetone and hydrogen sulfide molecules. Nanoscale $2015,7,16417-16426$

[147] Filice, M.; Marciello, M.; Morales, M.P.; Palomo, J.M. Synthesis of heterogeneous enzyme-metal nanoparticle biohybrids in aqueous media and their applications in C-C bond formation and tandem catalysis. Chem. Commun. 2013, 49, 6876-6878.

[148] Stadelmann W. K., Digenis A. G., and Tobin G. R., Physiology and healing dynamics of chronic cutaneous wounds, The American Journal of Surgery, 176(2), supplement 1, pp. 26S-38S, 1998.

[149] Steed D. L., The role of growth factors in wound healing, Surgical Clinics of North America, 1997, 77( 3), 575-586.

[150] Simpson D. M. and Ross R., The neutrophilic leukocyte in wound repair a study with antineutrophil serum, Journal of Clinical Investigation, 1972, 51(8), 2009-2023.

[151] M. B. Witte and A. Barbul, General principles of wound healing, Surgical Clinics of North America, 1997, 77(3), 509- 528.

[152] Cooper D. M., Optimizing wound healing. A practice within nursing's domain, Nursing Clinics of North America, 1990, 25(1), 165180.

[153] Madden J. W. and Peacock E. E., Studies on the biology of collagen during wound healing. I. Rate of collagen synthesis and deposition in cutaneous wounds of the rat, Surgery, 1968, 64(1), 288-294.

[154] Bennett N. T. and Schultz G. S., Growth factors and wound healing: part II. Role in normal and chronic wound healing, The American Journal of Surgery, 1993, 166(1), 74-81. 
Nath et al., Adv. Nan. Res.; Vol. 2 Issue 1, pp: 14-31, 2019

[155] Chen C., Schultz G. S., Bloch M., Edwards P. D., Tebes S., and Mast B. A., Molecular and mechanistic validation of delayed healing rat wounds as a model for human chronic wounds, Wound Repair and Regeneration, 1999, 7(6), 486-494.

[156] Yager D. R., Chen S.M., Ward S. I., Olutoye O. O., Diegelmann R. F., and Cohen I. K., Ability of chronic wound fluids to degrade peptide growth factors is associated with increased levels of elastase activity and diminished levels of proteinase inhibitors, Wound Repair and Regeneration. 1997, 5(1), 23-32.

[157] Nandhini J, Neeraja P, Rajkumar SRJ, Umapathy V, Suresh S (2017) Comparative studies of microwave and Sol-Gel-assisted combustion methods of $\mathrm{NiFe} 2 \mathrm{O} 4$ nanostructures: synthesis, structural, morphological, opto-magnetic, and antimicrobial activity. Journal of Superconductivity and Novel Magnetism 30(5): 1213-1220.

[158] Rai M, Yadav A, Gade A Silver nanoparticles as a new generation of antimicrobials. Biotechnology adv 2009, 27(1): 76-83.

[159] Mosae Selvakumar P, Antonyraj CA, Babu R, Dakhsinamurthy A, Manikandan N, et al. Green synthesis and antimicrobial activity of monodispersed silver nanoparticles synthesized using lemon extract. Synthesis and Reactivity in Inorganic Metal-Organic and Nano- Metal Chemistry 2016, 46(2): 291-294.

[160] Kiruba V. S. A., Dakshinamurthy A, Subramanian PS, Mosae Selvakumar P Green synthesis of biocidal silver-activated charcoal nanocomposite for disinfecting water. Journal of Experimental Nanoscience 2015, 10(7): 532-544.

[161] Deena S, Dakshinamurthy A, Mosae Selvakumar P Green Synthesis of Silver Nanoparticle Using Banana (Musa) Sap. Advanced Materials Research 2015, 1086: 7-10.

[162] Mariselvam R, Ranjitsingh AJA, Usha Raja Nanthini A, Kalirajan K, Padmalatha C, et al. Green synthesis of silver nanoparticles from the extract of the inflorescence of Cocos nucifera (Family: Arecaceae) for enhanced antibacterial activity. Spectrochimica Acta Part A, Molecular and Biomolecular Spectroscopy 2014, 129: 537-541.

[163] Arputha Kiruba VS, Dakshinamurthy A, Selvakumar PM Ecofriendly biocidal silver-activated charcoal nanocomposite: Application in water purification. Synthesis and Reactivity in Inorganic, Metal- Organic, and Nano-Metal Chemistry 2013, 43(8): 1068-1072.

[164] Kiruba VSA, Selvakumar PM, Dakshinamurthy A Biocidal Nano- Silver Reinforced Activated Charcoal in Water Treatment. Synthesis and Reactivity in Inorganic, Metal-Organic, and Nano-Metal Chemistry 2015, 45(10): 1570-1575.

[165] Ruparelia JP, Chatterjee AK, Duttagupta SP, Mukherji S Strain specificity in antimicrobial activity of silver and copper nanoparticles. Acta Biomater 2008, 4(3): 707-716.

[166] Kim J.S., Kuk E., Yu K.N., Kim J.H., Park S.J., et al. Antimicrobial effects of silver nanoparticles. Nanomedicine 2007, 3(1): 95-101.

[167] Widgerow A. D., Nanocrystalline silver, gelatinases and the clinical implications, Burns, 2010, 36(7), 965-974.

[168] Liu X., Lee P. Y., Ho C. M. et al., Silver nanoparticles mediate differential responses in keratinocytes and fibroblasts during skin wound healing, Chem Med Chem, 2010, 5(3), 468-475.

[169] Ai J., Biazar E., Jafarpour M. et al., Nanotoxicology and nanoparticle safety in biomedical designs, International Journal of Nanomedicine, 2011, 6, 1117-1127.

[170] Bhattacharya R, Mukherjee P Biological properties of "naked" metal nanoparticles. Adv Drug Deliv Rev 2008, 60(11): 1289-1306.

[171] Leu J.G., Chen S.A., Chen H.M., Wu W.M., Hung C.F . The effects of gold nanoparticles in wound healing with antioxidant epigallocatechin gallate and $\alpha$-lipoic acid. Nanomedicine 2012, 8(5): 767-775.

[172] Chen S.A., Chen H.M., Yao Y.D., Hung C.F., Tu C.S., et al. Topical treatment with anti-oxidants and Au nanoparticles promote , ealing of diabetic wound through receptor for advance glycation end-products. Eur J Pharm Sci 2012, 47(5): 875-883.

[173] Mariselvam R, Ranjitsingh A.J.A. , Padmalatha C, Mosae Selvakumar P Green Synthesis of Copper Quantum Dots using Rubia cardifolia Plant Root Extracts and its Antibacterial Properties. Journal of Academia and Industrial Research 2014, 3(4).

[174] Boateng J.S., Matthews K.H., Stevens H.N., Eccleston G.M. Wound healing dressings and drug delivery systems: a review. J Pharm Sci 2008, 97(8): 2892-2923.

[175] Bowler PG, Duerden BI, Armstrong DG Wound microbiology and associated approaches to wound management. Clin Microbiol Rev 2001, 14(2): 244-269.

[176] Newman MD, Stotland M, Ellis JI The safety of nanosized particles in titanium dioxide-and zinc oxide-based sunscreens. J Am Acad Dermatol 2009, 61(4): 685-692.

[177] Sankar R, Dhivya R, Shivashangari KS, Ravikumar V Wound healing activity of Origanum vulgare engineered titanium dioxide nanoparticles in Wistar Albino rats. J Mater Sci Mater Med 2014, 25(7): 1701-1708.

[178] Khil M.S., Cha D.I., Kim H.Y., Kim I.S., Bhattarai N Electrospun nanofibrous polyurethane membrane as wound dressing. J Mater Sci Mater Med 2003, 67(2): 675-679.

[179] Wang C.C., Su C.H., Chen C.C. Water absorbing and antibacterial properties of N-isopropyl acrylamide grafted and collagen/chitosan immobilized polypropylene nonwoven fabric and its application on wound healing enhancement. J Biomed Mater Res A 2008, 84(4): 1006-1017.

[180] Barnes C.P., Sell S.A., Boland E.D., Simpson D.G., Bowlin G.L. Nanofiber technology: designing the next generation of tissue engineering scaffolds. Advanced drug delivery reviews 2007, 59(14): 1413- 1433.

[181] Chong E.J., Phan T.T., Lim I.J., Zhang Y.Z., Bay B.H., et al. Evaluation of electrospun PCL/gelatin nanofibrous scaffold for wound healing and layered dermal reconstitution. Acta biomater 2007, 3(3): 321-330.

[182] Drakonakis, Vasileios M, Velisaris, Chris N, Seferis, et al. Matrix hybridization in the interlayer for carbon fiber reinforced composites. Polymer Composites 2010, 31(11): 1965-1976.

[183] Bosi S, Ballerini L, Prato M Carbon nanotubes in tissue engineering. In Making and Exploiting Fullerenes, Graphene, and Carbon Nanotubes. Springer Berlin Heidelberg 2013, 181-204.

[184] Schwentker A, Vodovotz Y, Weller R, Billiar TR Nitric oxide and wound repair: role of cytokines? Nitric oxide 2002, 7(1): 1-10.

[185] Louis J.I Nitric oxide: biology and pathobiology. Academic press.2000, 1017.

[186] Williams DLH A chemist's view of the nitric oxide story. Organic \& biomolecular chemistry 2003, 1(3): 44-449.

[187] Chen W.Y., Chang H.Y., Lu J.K., Huang Y.C., Harroun S.G., et al. Self-Assembly of Antimicrobial Peptides on Gold Nanodots: Against Multidrug-Resistant Bacteria and Wound-Healing Application. Advanced Functional Materials, 2015, 25(46): 7189-7199.

[188] Ou J. L., Mizushina Y, Wang, S.Y., Chuang D.Y., Nada M, et al. Structure-activity relationship analysis of curcumin analogues on antiinfluenza virus activity. The FEBS journal 2013, 280(22): 5829-5840. 
Green Peptide-nanomaterials; A Friendly Healing Touch for Skin Wound Regeneration

[189] Chereddy K.K., Coco R., Memvanga P.B., Ucakar, B., des AR, et al.. Combined effect of PLGA and curcumin on wound healing activity. Journal of controlled release 2013, 171(2): 208-215.

[190] Hurlow J. and Bowler P. G., Clinical experience with wound biofilm and management: a case series, Ostomy Wound Management 2009, 55(4), 38-49.

[191] Qadan M. and Cheadle W. G., CommonMicrobial Pathogens in Surgical Practice, Surgical Clinics of North America, 2009, 89(2), 295-310.

[192] Walker, M. R.; Patel, K. K.; Stappenbeck, T. S. The stem cell niche. J. Pathol. 2009, 217, 169-180.

[193] Blanpain, C.; Lowry, W. E.; Geoghegan, A.; Polak, L.; Fuchs, E. Self-renewal, multipotency, and the existence of two cell populations within an epithelial stem cell niche. Cell 2004, 118, 635-648.

[194] Ma, K.; Liao, S.; He, L.; Lu, J.; Ramakrishna, S.; Chan, C. K. Effects of nanofiber/stem cell composite on wound healing in acute full-thickness skin wounds. Tissue Eng., Part A 2011, 17, 1413-1424.

[195] Metcalfe, A. D.; Ferguson, M. W. Tissue engineering of replacement skin: the crossroads of biomaterials, wound healing, embryonic development, stem cells and regeneration. J. R. Soc., Interface 2007, 4, 413-437.

[196] Kalashnikova, I.; Das, S.; Seal, S. Nanomaterials for wound healing: scope and advancement. Nanomedicine 2015, 10, $2593-2612$.

[197] Chen, S.-A.; Chen, H.-M.; Yao, Y.-D.; Hung, C.-F.; Tu, C.-S.; Liang, Y.-J. Topical treatment with anti-oxidants and Au nanoparticles promote healing of diabetic wound through receptor for advance glycation end-products. Eur. J. Pharm. Sci. 2012, 47, 875-883.

[198] Chen, W. Y.; Chang, H. Y.; Lu, J. K.; Huang, Y. C.; Harroun, S. G.; Tseng, Y. T.; Li, Y. J.; Huang, C. C.; Chang, H. T. Self-Assembly of Antimicrobial Peptides on Gold Nanodots: Against Multidrug- Resistant Bacteria and Wound-Healing Application. Adv. Funct. Mater. 2015, 25, 7189-7199.

Publish your research article in AIJR journals-

$\checkmark$ Online Submission and Tracking

$\checkmark$ Peer-Reviewed

$\checkmark$ Rapid decision

$\checkmark \quad$ Immediate Publication after acceptance

$\checkmark$ Articles freely available online

$\checkmark \quad$ Retain full copyright of your article.

Submit your article at journals.aijr.in
Publish your books with AIJR publisher-

$\checkmark$ Publish with ISBN and DOI.

$\checkmark$ Publish Thesis/Dissertation as Monograph.

$\checkmark$ Publish Book Monograph.

$\checkmark$ Publish Edited Volume/ Book.

$\checkmark$ Publish Conference Proceedings

$\checkmark \quad$ Retain full copyright of your books.

Submit your manuscript at books.aijr.org 